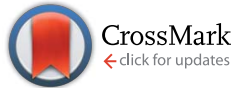

Cite this: RSC Adv., 2015, 5, 48516

Received 24th April 2015 Accepted 22nd May 2015

DOI: $10.1039 / c 5 r a 07449 e$

www.rsc.org/advances

\section{Copper(I)-based dye-sensitized solar cells with sterically demanding anchoring ligands: bigger is not always better $\phi$}

\author{
Sven Y. Brauchli, Frederik J. Malzner, Edwin C. Constable \\ and Catherine E. Housecroft*
}

The synthesis and characterization of ((6,6'-diphenyl-[2,2'-bipyridine]-4,4'-diyl)bis(4,1-phenylene)) bis(phosphonic acid), 2, are described. Compound 2 has been incorporated as an anchoring ligand in copper(I)-containing dyes in n-type dye-sensitized solar cells (DSCs), combined with 2,2'-bipyridine (bpy), 6-methyl-2,2'-bipyridine (6-Mebpy), 6,6'-dimethyl-2,2'-bipyridine (6,6'-Me $2_{2}$ bpy), 4,4'-di(4bromophenyl)-6,6'-dimethyl-2,2'-bipyridine (3) or 4,4'-di(4-bromophenyl)-6,6'-diphenyl-2,2' -bipyridine (4) as ancillary ligands ( $L_{\text {ancillary }}$ ). Dyes were assembled on mesoporous $\mathrm{TiO}_{2}$ using an on-surface assembly strategy which relies on ligand exchange between surface-anchored $L_{\text {anchor }}$ and $\left[\mathrm{Cu}\left(\mathrm{L}_{\text {ancillary }}\right)_{2}\right]^{+} ;{ }^{1} \mathrm{H}$ NMR spectroscopy was used to confirm that the bulky phenyl substituents did not hinder ligand exchange. Comparison of values of the open-circuit voltages $\left(V_{O C}\right)$, short-circuit current densities $\left(\mathrm{J}_{\mathrm{SC}}\right)$ and external quantum efficiency (EQE) spectra for DSCs with model dyes $[\mathrm{Cu}(2)(\mathrm{bpy})]^{+}$, $[\mathrm{Cu}(2)(6-\mathrm{Mebpy})]^{+}$and $\left[\mathrm{Cu}(2)\left(6,6^{\prime}-\mathrm{Me}_{2} \mathrm{bpy}\right)\right]^{+}$confirm that methyl-substituents in $\mathrm{L}_{\text {ancillary }}$ are beneficial. Performance data for DSCs with dyes $[\mathrm{Cu}(1)(3)]^{+},[\mathrm{Cu}(1)(4)]^{+},[\mathrm{Cu}(2)(3)]^{+}$and $[\mathrm{Cu}(2)(4)]^{+}$where 1 is the anchor ((6,6'-dimethyl-[2,2' -bipyridine]-4,4'-diyl)bis(4,1-phenylene))bis(phosphonic acid) show that dyes with anchor 2 (phenyl substituents in the 6 - and $6^{\prime}$-positions) give relative conversion efficiencies $\leq 10 \%$ with respect to standard dye N719 set at $\eta=100 \%$; this compares with relative efficiencies of up to $34.5 \%$ for the dyes $[\mathrm{Cu}(1)(3)]^{+}$and $[\mathrm{Cu}(1)(4)]^{+}$. The performance of $[\mathrm{Cu}(2)(3)]^{+}$can be improved by the addition of the co-adsorbant chenodeoxycholic acid. Although the phenyl (versus methyl) substituents lead to enhanced light absorption to lower energies, dyes with anchor 2 quickly bleach when exposed to the $\mathrm{I}^{-} / \mathrm{I}_{3}^{-}$electrolyte; bleaching also occurs after soaking in solutions of Lil. The dye can be regenerated by treatment of a bleached electrode with $\mathrm{L}_{\text {ancillary, }}$ or with $\left[\mathrm{Cu}(\mathrm{NCMe})_{4}\right]^{+}$followed by $\mathrm{L}_{\text {ancillary }}$.

\section{Introduction}

In the last few years, there has been significant progress in the development of n-type dye sensitized solar cells (DSCs) incorporating copper(I)-based dyes ${ }^{\mathbf{1 , 2}}$ in place of the ruthenium(II) sensitizers used in conventional Grätzel DSCs. ${ }^{3}$ This move away from metals scarce on Earth is mirrored in the development of copper(I) complexes for organic light-emitting devices (OLEDs) ${ }^{4}$ and light-emitting electrochemical cells (LECs) ${ }^{5,6}$ Compared to efficiencies of $>12 \%$ for ruthenium- or porphyrin-based dyes or metal-free organic dyes, ${ }^{7}$ photoconversion efficiencies for copper(I)-based DSCs only recently surpassed 3\% (relative to $7.63 \%$ for reference dye N719) for masked and sealed cells. ${ }^{8}$ In 2014, Boujtita, Odobel and coworkers ${ }^{9}$ reported a dramatic improvement in efficiency, achieving $4.66 \%$ (relative to $7.36 \%$ for $\mathrm{N} 719$ )

Department of Chemistry, University of Basel, Spitalstrasse 51, CH-4056 Basel, Switzerland. E-mail: catherine.housecroft@unibas.ch; Tel: +41612671008 $\uparrow$ Electronic supplementary information (ESI) available: Fig. S1. NMR spectrum for $\left[\mathrm{Cu}(3)_{2}\right]\left[\mathrm{PF}_{6}\right] /\left[\mathrm{Cu}(4)_{2}\right]\left[\mathrm{PF}_{6}\right]$ ligand exchange. See DOI: $10.1039 / \mathrm{c} 5 \mathrm{ra07449e}$ for the copper(I) dye shown in Scheme 1 in sealed DSCs. Factors that contribute to this impressive efficiency are the use of a $2,2^{\prime}$ bipyridine (bpy) ancillary ligand bearing peripheral triethylamino domains and conjugated spacers, a bpy anchoring ligand with bulky mesityl groups in the 6,6'-positions, and the addition of a co-adsorbant (chenodeoxycholic acid, cheno).

Bis(diimine)copper(I) complexes are labile making isolation of heteroleptic complexes in solution difficult; unless steric factors dictate otherwise, statistical mixtures of homo- and heteroleptic species are obtained. ${ }^{\mathbf{1 0}}$ The HETPHEN approach which relies on bulky substituents ${ }^{\mathbf{1 1}}$ is successfully used to prepare heteroleptic copper(I) dyes prior to adsorption on the electrode surface., ${ }^{\mathbf{9} 2}$ In contrast, we have introduced an onsurface strategy in which $\mathrm{TiO}_{2}$ functionalized with an anchoring ligand, $\mathrm{L}_{\text {anchor }}$, acts as a 'surface-as-ligand' to bind a metal ion ('surface-as-complex') followed by an ancillary ligand, $\mathrm{L}_{\text {ancillary }}{ }^{\mathbf{1 3 , 1 4}}$ This versatile approach allows facile screening of heteroleptic dyes comprising carboxylic or phosphonic acid anchoring ligands with different ancillary ligands, ${ }^{\mathbf{8} 13-19}$ and we have also used the method to assess the different performances 


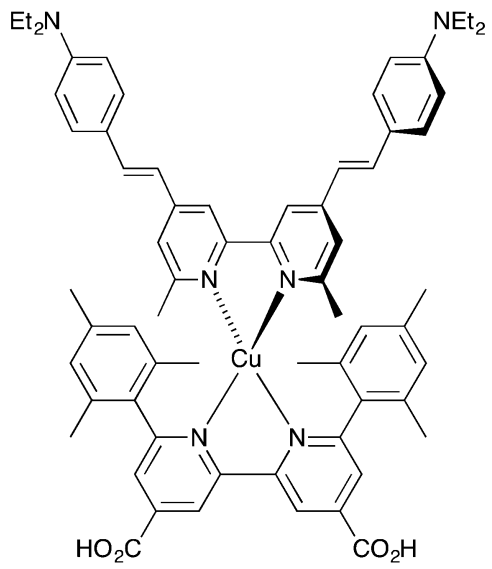

Scheme 1 State-of-the-art copper(I) dye in DSCs reported by Boujtita, Odobel and coworkers. ${ }^{9}$

of dyes with phosphonic acid or phosphonate ester anchoring domains. ${ }^{20}$ To stabilize tetrahedral $\left[\mathrm{Cu}\left(\mathrm{N}^{\wedge} \mathrm{N}\right)_{2}\right]^{+}$complexes in which $\mathrm{N}^{\wedge} \mathrm{N}$ is a bpy or phen (phen $=1,10$-phenanthroline) against oxidation to square planar $\left[\mathrm{Cu}\left(\mathrm{N}^{\wedge} \mathrm{N}\right)_{2}\right]^{2+}$, it is necessary to introduce substituents in the $6,6^{\prime}$ - or 2,9-positions, respectively, of bpy or phen. ${ }^{21}$ For $\mathrm{L}_{\text {anchor }}$, we have focused on $6,6^{\prime}$ dimethyl-2,2'-bipyridines and shown that $\mathbf{1}$ (Scheme 2) is the most effective anchor of the carboxylic and phosphonic acids screened so far. ${ }^{13,16}$ The electronic properties of bpy-based $\mathrm{L}_{\text {ancillary }}$ are readily tuned by variation in the $4,4^{\prime}$ - and/or $6,6^{\prime}$ substituents. Bromo or iodo-substituents in the $4,4^{\prime}$-positions appear particularly beneficial, ${ }^{\mathbf{8}, 16}$ and phenyl groups in the 6,6'positions lead to enhanced absorption at higher wavelengths. ${ }^{\mathbf{1 6}}$ The latter is an important point, since a major challenge for further development of copper(I) dyes is to broaden the spectral response in the red-end of the visible region., ${ }^{\mathbf{9}, 16}$

We now report the preparation and characterization of the phosphonic acid anchor 2 (Scheme 2) with phenyl substituents in the 6,6'-positions of the bpy domain, and compare its performance with the dimethyl analogue 1 (Scheme 2) when combined with ancillary ligands 3 or 4 . We also assess the need for $6,6^{\prime}$-substituents in $\mathrm{L}_{\text {ancillary }}$ in the $\left[\mathrm{Cu}\left(\mathrm{N}^{\wedge} \mathrm{N}\right)_{2}\right]^{+}$dye when $\mathrm{L}_{\text {anchor }}$ contains sterically demanding phenyl substituents.
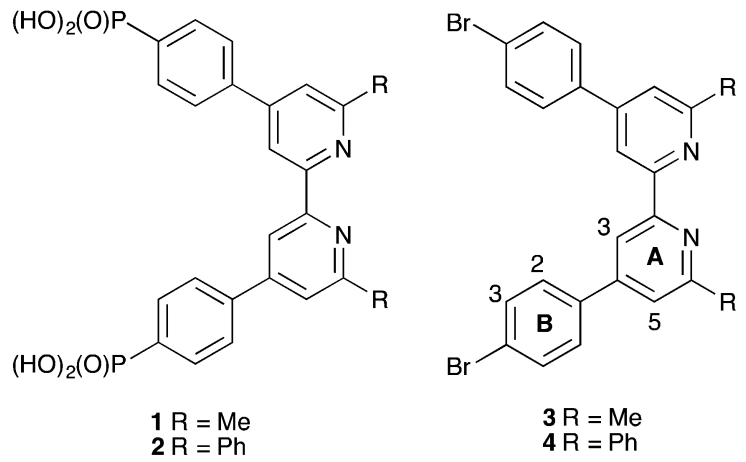

Scheme 2 Structures of anchoring ligands 1 and 2, and ancillary ligands 3 and 4 . Ring labelling for NMR assignments in 3 and 4 are shown; the Ph substituent is ring $\mathrm{C}$.

\section{Experimental}

\section{General}

${ }^{1} \mathrm{H}$ and ${ }^{13} \mathrm{C}$ NMR spectra were recorded at $295 \mathrm{~K}$ on a Bruker Avance III-500 NMR spectrometer with chemical shifts referenced to residual solvent peaks with respect to $\delta(\mathrm{TMS})=0 \mathrm{ppm}$. Solid-state absorption spectra were recorded on a Cary 5000 spectrophotometer, and FT-IR spectra on a Perkin-Elmer Spectrum two spectrometer equipped with a UATR. Electrospray ionization (ESI) mass spectra were measured using a Bruker Esquire 3000 Plus mass spectrometer. A Biotage Initiator 8 reactor was used for microwave reactions.

\section{Ligands and complexes}

Ligands $\quad \mathbf{1 ,}^{\mathbf{1 6}} \quad \mathbf{3 ,}^{\mathbf{2 2}} \mathbf{4 , { } ^ { 1 6 }}\left[\mathrm{Cu}(\mathrm{MeCN})_{4}\right]\left[\mathrm{PF}_{6}\right],{ }^{23} \quad\left[\mathrm{Cu}(3)_{2}\right]\left[\mathrm{PF}_{6}\right],^{16}$ $\left[\mathrm{Cu}(4)_{2}\right]\left[\mathrm{PF}_{6}\right],{ }^{16}\left[\mathrm{Cu}(6-\mathrm{Mebpy})_{2}\right]\left[\mathrm{PF}_{6}\right]^{13}$ and $\left[\mathrm{Cu}\left(6,6^{\prime}-\mathrm{Me}_{2} \mathrm{bpy}\right)_{2}\right]\left[\mathrm{PF}_{6}\right]^{15}$ were synthesized as previously reported.

Abbreviations: 6-Mebpy $=6$-methyl-2,2'-bipyridine, 6,6'$\mathrm{Me}_{2}$ bpy = 6,6'-dimethyl-2,2'-bipyridine, 2,9- $\mathrm{Me}_{2}$ phen $=$ 2,9dimethyl-1,10-phenanthroline.

\section{Compound 5}

Compound 4 (247 mg, $0.399 \mathrm{mmol}),\left[\mathrm{Pd}\left(\mathrm{PPh}_{3}\right)_{4}\right](138 \mathrm{mg}$, $0.12 \mathrm{mmol}$ ) and $\mathrm{Cs}_{2} \mathrm{CO}_{3}(325 \mathrm{mg}, 0.999 \mathrm{mmol})$ were combined in anhydrous THF $(20 \mathrm{~mL})$ in a $10-20 \mathrm{~mL}$ microwave vial equipped with a stirrer bar under argon. Diethylphosphite $(0.12 \mathrm{~g}, 0.11 \mathrm{~mL}, 0.88 \mathrm{mmol})$ was added by syringe before the vial was sealed and the reaction mixture was heated under microwave irradiation to $110{ }^{\circ} \mathrm{C}$ for $150 \mathrm{~min}$. The reaction mixture was filtered to yield a yellow solution prior to evaporation of the solvent under reduced pressure. The resulting yellow residue was then dissolved in $\mathrm{CH}_{2} \mathrm{Cl}_{2}(20 \mathrm{~mL})$ and stirred with decolourising charcoal for $10 \mathrm{~min}$ then filtered over Celite prior to removal of solvent under reduced pressure to produce an oily yellow residue which crystallized quickly. Upon addition of acetone $(20 \mathrm{~mL})$, a white precipitate formed. The white solid was collected by filtration, washed with $\mathrm{Et}_{2} \mathrm{O}(20 \mathrm{~mL})$ and dried under a stream of air, yielding 5 as a white solid (161 mg, $0.220 \mathrm{mmol}, 55.1 \%)$. M.p. $255{ }^{\circ} \mathrm{C} .{ }^{1} \mathrm{H}$ NMR (500 $\mathrm{MHz}, \mathrm{CDCl}_{3}$ ) $\delta / p p m 8.91\left(\mathrm{~d}, J=1.5 \mathrm{~Hz}, 2 \mathrm{H}, \mathrm{H}^{\mathrm{A} 3}\right), 8.22\left(\mathrm{~m}, 4 \mathrm{H}, \mathrm{H}^{\mathrm{C} 2}\right), 8.04(\mathrm{~m}$, $\left.6 \mathrm{H}, \mathrm{H}^{\mathrm{A} 5+\mathrm{B} 3}\right), 7.97\left(\mathrm{~m}, 4 \mathrm{H}, \mathrm{H}^{\mathrm{B} 2}\right), 7.57\left(\mathrm{~m}, 4 \mathrm{H}, \mathrm{H}^{\mathrm{C} 3}\right), 7.51(\mathrm{~m}, 2 \mathrm{H}$, $\left.\mathrm{H}^{\mathrm{C} 4}\right), 4.18\left(\mathrm{~m}, 8 \mathrm{H}, \mathrm{H}^{\mathrm{OEt}}\right), 1.38\left(\mathrm{t}, J=7.1 \mathrm{~Hz}, 12 \mathrm{H}, \mathrm{H}^{\mathrm{OEt}}\right) .{ }^{13} \mathrm{C} \mathrm{NMR}$ $\left(126 \mathrm{MHz}, \mathrm{CDCl}_{3}\right) \delta /$ ppm $157.6\left(\mathrm{C}^{\mathrm{A} 6}\right), 156.0\left(\mathrm{C}^{\mathrm{A} 2}\right), 149.8\left(\mathrm{C}^{\mathrm{A} 4}\right)$, $142.8\left(\mathrm{C}^{\mathrm{B} 1}\right), 138.8\left(\mathrm{C}^{\mathrm{C} 1}\right), 132.8\left(\mathrm{~d}, J_{\mathrm{PC}}=11.0 \mathrm{~Hz}, \mathrm{C}^{\mathrm{B} 3}\right), 129.7\left(\mathrm{C}^{\mathrm{C} 4}\right)$, $129.1\left(\mathrm{C}^{\mathrm{C} 3}\right), 128.6\left(\mathrm{C}^{\mathrm{B} 4}\right), 127.7\left(\mathrm{~d}, J_{\mathrm{PC}}=15.5 \mathrm{~Hz}, \mathrm{C}^{\mathrm{B} 2}\right), 127.5\left(\mathrm{C}^{\mathrm{C} 2}\right)$, $119.3\left(\mathrm{C}^{\mathrm{A} 5}\right), 118.8\left(\mathrm{C}^{\mathrm{A} 3}\right), 62.5\left(\mathrm{~d}, J_{\mathrm{PC}}=5.5 \mathrm{~Hz}, \mathrm{C}^{\mathrm{OCH} 2}\right), 16.6\left(\mathrm{~d}, J_{\mathrm{PC}}\right.$ $=6.5 \mathrm{~Hz}, \mathrm{C}^{\mathrm{OCH} 2 \mathrm{CH} 3}$ ). IR (solid, $\nu \mathrm{cm}^{-1}$ ) $3070(\mathrm{w}), 3037(\mathrm{w}), 2983$ (w), 2937 (w), 2905 (w), 1592 (s), 1539 (m), 1379 (m), 1243 (s), 1132 (m), 1050 (s), 1022 (s), 955 (s), 776 (s), 682 (s), 572 (s), 518 (m). ESI MS $m / z$ 733.6 $[\mathrm{M}+\mathrm{H}]^{+}$(calc. 733.3). Found $\mathrm{C} 68.83, \mathrm{H}$ 5.83, $\mathrm{N} 3.96, \mathrm{C}_{42} \mathrm{H}_{42} \mathrm{~N}_{2} \mathrm{O}_{6} \mathrm{P}_{2}$ requires $\mathrm{C} 68.84, \mathrm{H} 5.78, \mathrm{~N} 3.82 \%$.

\section{Compound 2}

Compound 5 (121 mg, $0.165 \mathrm{mmol}$ ) was dissolved in concentrated aqueous $\mathrm{HCl}$ and the solution was heated at reflux for 
$48 \mathrm{~h}$. Solvent was removed under reduced pressure leaving an off-white residue. This was added to glacial acetic acid $(35 \mathrm{~mL})$ and concentrated aqueous $\mathrm{HCl}(1 \mathrm{~mL})$ and the mixture was heated at reflux for $24 \mathrm{~h}$. After cooling to room temperature and standing for $24 \mathrm{~h}$, a pale yellow powder precipitated and this was collected by filtration. After washing with water $(10 \mathrm{~mL})$, acetone $(10 \mathrm{~mL})$ and $\mathrm{Et}_{2} \mathrm{O}(20 \mathrm{~mL}), 2$ was isolated as off-white solid (65.9 mg, $0.108 \mathrm{mmol}, 65.5 \%$ ). M.p. > $350{ }^{\circ} \mathrm{C} .{ }^{1} \mathrm{H}$ NMR $\left(500 \mathrm{MHz}, \mathrm{DMSO}-d_{6}\right) \delta / \mathrm{ppm} 8.82\left(\mathrm{~d}, J=1.6 \mathrm{~Hz}, 2 \mathrm{H}, \mathrm{H}^{\mathrm{A} 3}\right), 8.40(\mathrm{~d}$, $\left.J=7.3 \mathrm{~Hz}, 4 \mathrm{H}, \mathrm{H}^{\mathrm{C} 2}\right), 8.38\left(\mathrm{~d}, J=1.7 \mathrm{~Hz}, 2 \mathrm{H}, \mathrm{H}^{\mathrm{A} 5}\right), 8.13\left(\mathrm{dd}, J_{\mathrm{HH}}=\right.$ $\left.8.2 \mathrm{~Hz}, J_{\mathrm{PH}}=3.1 \mathrm{~Hz}, 4 \mathrm{H}, \mathrm{H}^{\mathrm{B} 2}\right), 7.90\left(\mathrm{dd}, J_{\mathrm{PH}}=12.6 \mathrm{~Hz}, J_{\mathrm{HH}}=\right.$ $\left.7.8 \mathrm{~Hz}, 4 \mathrm{H}, \mathrm{H}^{\mathrm{B} 3}\right), 7.60\left(\mathrm{t}, J=7.6 \mathrm{~Hz}, 4 \mathrm{H}, \mathrm{H}^{\mathrm{C} 3}\right), 7.53\left(\mathrm{~m}, 2 \mathrm{H}, \mathrm{H}^{\mathrm{C} 4}\right)$. ${ }^{13} \mathrm{C}$ NMR $\left(126 \mathrm{MHz}\right.$, DMSO- $\left.d_{6}\right) \delta /$ ppm $156.6\left(\mathrm{C}^{\mathrm{A} 6}\right), 155.8\left(\mathrm{C}^{\mathrm{A} 2}\right)$, $149.0\left(\mathrm{C}^{\mathrm{A} 4}\right), 139.9\left(\mathrm{C}^{\mathrm{B} 1}\right), 138.4\left(\mathrm{C}^{\mathrm{C} 1}\right), 135.1\left(\mathrm{~d}, J_{\mathrm{PC}}=178 \mathrm{~Hz}, \mathrm{C}^{\mathrm{B} 4}\right)$, $131.4\left(\mathrm{C}^{\mathrm{B} 3}\right), 129.4\left(\mathrm{C}^{\mathrm{C} 4}\right), 128.8\left(\mathrm{C}^{\mathrm{C} 3}\right), 127.1\left(\mathrm{C}^{\mathrm{B} 2+\mathrm{C} 2}\right), 118.7\left(\mathrm{C}^{\mathrm{A} 5}\right)$, $117.2\left(\mathrm{C}^{\mathrm{A} 3}\right)$. IR (solid, $\nu \mathrm{cm}^{-1}$ ): $3617(\mathrm{w}), 3323(\mathrm{w}), 3058(\mathrm{w}), 3037$ (w), 1619 (m), 1592 (s), $1533(\mathrm{~m}), 1377(\mathrm{~m}), 1244(\mathrm{w}), 1136(\mathrm{~s})$, $986(\mathrm{~m}), 924(\mathrm{~s}), 824(\mathrm{~s}), 768(\mathrm{~m}), 677(\mathrm{~s}), 638(\mathrm{~m}), 550(\mathrm{~s}), 506$ (m). ESI MS (in MeOH/TFA) $m / z 621.4[\mathrm{M}+\mathrm{H}]^{+}$(calc. 621.1). Satisfactory elemental analysis could not be obtained.

\section{$\left[\mathrm{Cu}(\mathrm{bpy})_{2}\right]\left[\mathrm{PF}_{6}\right]$}

The complex $\left[\mathrm{Cu}(\mathrm{bpy})_{2}\right]\left[\mathrm{PF}_{6}\right]$ was not isolated. The relevant dyebath for the DSC assembly (see below) was prepared using a $0.1 \mathrm{mM} \mathrm{CH}_{2} \mathrm{Cl}_{2}$ solution of $\left[\mathrm{Cu}(\mathrm{MeCN})_{4}\right]\left[\mathrm{PF}_{6}\right]$ and two equivalents of bpy.

\section{DSC fabrication and measurements}

DSCs were made based on the method of Grätzel and coworkers. $^{24,25}$ Solaronix Test Cell Titania Electrodes were used for the photoanodes. They were washed with EtOH and sintered at $450{ }^{\circ} \mathrm{C}$ for $30 \mathrm{~min}$, then cooled to $\approx 80{ }^{\circ} \mathrm{C}$ and soaked in a $1.0 \mathrm{mM}$ DMSO solution of 1 or 2 for $24 \mathrm{~h}$ at a constant temperature of $28{ }^{\circ} \mathrm{C}$. Each electrode was removed from the solution, washed with DMSO and $\mathrm{CH}_{2} \mathrm{Cl}_{2}$ and dried at $\approx 60{ }^{\circ} \mathrm{C}$ (heat gun). Each functionalized electrode was then soaked for 3 days in a $0.1 \mathrm{mM} \mathrm{CH}_{2} \mathrm{Cl}_{2}$ solution of $\left[\mathrm{Cu}(\mathrm{bpy})_{2}\right]\left[\mathrm{PF}_{6}\right]$ (see above), $\left[\mathrm{Cu}\left(6-\mathrm{Mebpy}_{2}\right]\left[\mathrm{PF}_{6}\right],\left[\mathrm{Cu}\left(6,6^{\prime}-\mathrm{Me}_{2} \mathrm{bpy}\right)_{2}\right]\left[\mathrm{PF}_{6}\right],\left[\mathrm{Cu}(3)_{2}\right]\left[\mathrm{PF}_{6}\right]\right.$ or $\left[\mathrm{Cu}(4)_{2}\right]\left[\mathrm{PF}_{6}\right]$ at a constant dye-bath temperature of $28{ }^{\circ} \mathrm{C}$. The electrodes were then removed from the dye-bath and washed with $\mathrm{CH}_{2} \mathrm{Cl}_{2}$. For experiments with cheno, the electrodes with adsorbed 1 or 2 were soaked for 3 days in a dye-bath (at a constant $28{ }^{\circ} \mathrm{C}$ ) consisting of a $1: 1$ mixture of $0.1 \mathrm{mM} \mathrm{CH}_{2} \mathrm{Cl}_{2}$ solutions of cheno and $\left[\mathrm{Cu}(3)_{2}\right]\left[\mathrm{PF}_{6}\right]$ or $\left[\mathrm{Cu}(4)_{2}\right]\left[\mathrm{PF}_{6}\right]$.

N719 reference electrodes were prepared by soaking Solaronix Test Cell Titania Electrodes in a $0.3 \mathrm{mM}$ EtOH solution of dye N719 (Solaronix) for 3 days. The electrodes were taken out of the dye-bath, washed with EtOH and dried at $\approx 60{ }^{\circ} \mathrm{C}$ (heat gun).

For the counter electrodes, Solaronix Test Cell Platinum Electrodes were used, and volatile organic impurities were removed by heating on a heating plate at $450{ }^{\circ} \mathrm{C}$ for $30 \mathrm{~min}$.

The dye-covered $\mathrm{TiO}_{2}$ electrode and $\mathrm{Pt}$ counter-electrode were combined using thermoplast hot-melt sealing foil (Solaronix Test Cell Gaskets) by heating while pressing them together. The electrolyte ( $\mathrm{LiI}(0.1 \mathrm{M}), \mathrm{I}_{2}(0.05 \mathrm{M})$, 1-methylbenzimidazole (0.5 M), 1-butyl-3-methylimidazolinium iodide $(0.6 \mathrm{M})$ in 3-methoxypropionitrile) was introduced into the DSC by vacuum backfilling. The hole in the counter electrode was sealed with hot-melt sealing foil (Solaronix Test Cell Sealings) and a cover glass (Solaronix Test Cell Caps).

For each dye, duplicate DSCs were made. In the discussion, the optimal results are presented, but within experimental error, the performances of duplicate cells were similar. Measurements were made by irradiating from behind using a light source LOT Quantum Design LS0811 $\left(100 \mathrm{~mW} \mathrm{~cm}^{-2}=1\right.$ sun). The power of the simulated light was calibrated using a reference Si cell. All DSCs were completely masked ${ }^{26,27}$ before measurements were made.

\section{Solid-state absorption spectra of photoanodes: bleaching tests}

Solaronix Test Cell Titania Electrodes Transparent were washed with $\mathrm{EtOH}$ and sintered at $450{ }^{\circ} \mathrm{C}$ for $30 \mathrm{~min}$, then cooled to $\approx 80^{\circ} \mathrm{C}$ and soaked in a $1 \mathrm{mM}$ DMSO solution of 2 for $24 \mathrm{~h}$. Each electrode was removed from the solution, washed with DMSO and $\mathrm{CH}_{2} \mathrm{Cl}_{2}$ and dried at $\approx 60{ }^{\circ} \mathrm{C}$ (heat gun). Each functionalized electrode was then soaked for 3 days in a $0.1 \mathrm{mM} \mathrm{CH} \mathrm{Cl}_{2}$ solution of $\left[\mathrm{Cu}(3)_{2}\right]\left[\mathrm{PF}_{6}\right]$. The electrodes were removed from the dye-bath, washed with $\mathrm{CH}_{2} \mathrm{Cl}_{2}$ and dried at $\approx 60{ }^{\circ} \mathrm{C}$ (heat gun). Solid-state absorption spectra of the functionalized electrodes were recorded using a Cary-5000 spectrophotometer, before and after being dipped into $\mathrm{I}^{-} / \mathrm{I}_{3}{ }^{-}$electrolyte (composition as above) or a $0.1 \mathrm{M}$ solution of LiI in 3-methoxypropionitrile for $15 \mathrm{~min}$; after soaking, the electrode was washed with 3-methoxypropionitrile and $\mathrm{EtOH}$, dried at $\approx 80{ }^{\circ} \mathrm{C}$ (heat gun).

Adsorbed dyes were regenerated as follows. One bleached electrode was soaked in a $\mathrm{CH}_{2} \mathrm{Cl}_{2}$ solution of $3(0.1 \mathrm{mM})$ for 15 min, was then removed, washed with $\mathrm{CH}_{2} \mathrm{Cl}_{2}$ and dried with a heat gun at $80^{\circ} \mathrm{C}$. The other bleached electrode was dipped into a MeCN solution of $\left[\mathrm{Cu}(\mathrm{NCMe})_{4}\right]\left[\mathrm{PF}_{6}\right](2.0 \mathrm{mM})$ for $15 \mathrm{~min}$, was then removed, washed with $\mathrm{MeCN}$ and dried with a heat gun at $80{ }^{\circ} \mathrm{C}$; the electrode was then dipped in a $\mathrm{CH}_{2} \mathrm{Cl}_{2}$ solution of 3 (0.1 $\mathrm{mM}$ ) for $15 \mathrm{~min}$, before being washed with $\mathrm{CH}_{2} \mathrm{Cl}_{2}$ and dried as above.

\section{External quantum efficiencies}

External quantum efficiency (EQE) measurements were made using a Spe-Quest quantum efficiency instrument from Rera Systems (Netherlands) with a $100 \mathrm{~W}$ halogen lamp (QTH) and a lambda 300 grating monochromator (Lot Oriel). The monochromatic light was modulated to $3 \mathrm{~Hz}$ using a chopper wheel (ThorLabs). The cell response was amplified with a large dynamic range IV converter (CVI Melles Griot) and measured with a SR830 DSP Lock-In amplifier (Stanford Research).

\section{Results and discussion}

\section{Synthesis and characterization of anchoring ligand 2}

The synthetic route to 2 (Scheme 2) followed that reported for the 6,6'-dimethyl analogue 1 (ref. 16) and is summarized in Scheme 3. The precursor $\mathbf{4}$ was prepared as previously described $^{22}$ and was converted to the phosphonate ester $\mathbf{5}$ before deprotection using aqueous $\mathrm{HCl}$ and glacial acetic acid. 
Compound 2 was isolated in $65.5 \%$. The compound is poorly soluble in many organic solvents, and the electrospray mass spectrum was measured using a solution of 2 in $\mathrm{MeOH}$ with added $\mathrm{CF}_{3} \mathrm{CO}_{2} \mathrm{H}$. The base peak at $m / z 621.4$ arose from the $[\mathrm{M}+\mathrm{H}]^{+}$ion. A higher mass peak at $m / z 649.4$ was consistent either with the presence of monoethylphosphonate ester or with diesterification of 2 through reaction with $\mathrm{MeOH}$ solvent (i.e. $[\mathrm{M}-2 \mathrm{H}+2 \mathrm{Me}+\mathrm{H}]^{+}$, calc. 649.2). The fact that no ethyl signals appeared in the ${ }^{1} \mathrm{H}$ NMR spectrum of 2 was evidence that deprotection was complete and that esterification occurred during mass spectrometric analysis. The ${ }^{1} \mathrm{H}$ and ${ }^{13} \mathrm{C}$ NMR spectra (see Experimental section) of a DMSO- $d_{6}$ solution of 2 were in accord with the structure shown in Scheme 3; spectra were assigned using COSY, HMQC and HMBC methods.

\section{Ligand exchange between $\left[\mathrm{Cu}(3)_{2}\right]\left[\mathrm{PF}_{6}\right]$ and $\left[\mathrm{Cu}(4)_{2}\right]\left[\mathrm{PF}_{6}\right]$}

The stepwise assembly of a heteroleptic copper(I) dye by the method shown in Scheme 4 presupposes that ligand exchange occurs on a finite timescale. NMR spectroscopic studies have shown that ligand exchange between $\left[\mathrm{Cu}\left(6,6^{\prime}-\mathrm{Me}_{2} \mathrm{bpy}\right)_{2}\right]\left[\mathrm{PF}_{6}\right]$ and $\left[\mathrm{Cu}\left(2,9-\mathrm{Me}_{2} \text { phen }\right)_{2}\right]\left[\mathrm{PF}_{6}\right]$ occurs within the time of mixing

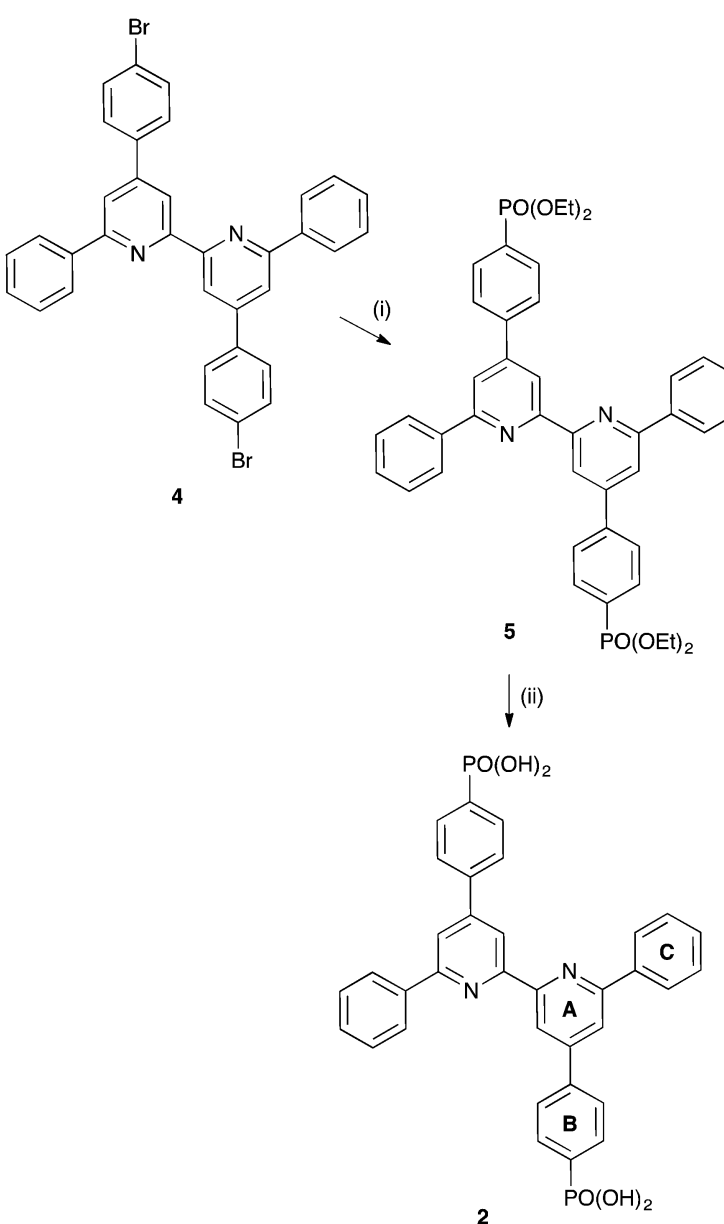

Scheme 3 Synthesis of 2: (i) $\left[\mathrm{Pd}\left(\mathrm{PPh}_{3}\right)_{4}\right], \mathrm{Cs}_{2} \mathrm{CO}_{3}, \mathrm{HPO}_{3} \mathrm{Et}_{2}, \mathrm{THF}$, microwave, $110{ }^{\circ} \mathrm{C}, 150 \mathrm{~min}$; (ii) conc. aq. $\mathrm{HCl}$, reflux, $48 \mathrm{~h}$; then glacial acetic acid and conc. $\mathrm{HCl}$, reflux, $24 \mathrm{~h}$. Ring labelling for NMR assignments in 2 are shown. in $\mathrm{CD}_{3} \mathrm{CN}$ solution with a statistical equilibrium mixture being formed. ${ }^{10}$ The present DSC study involves the stepwise assembly of the surface-bound heteroleptic dyes $[\mathrm{Cu}(\mathbf{1})(\mathbf{3})]^{+},[\mathrm{Cu}(\mathbf{1})(\mathbf{4})]^{+}$, $[\mathrm{Cu}(2)(3)]^{+}$and $[\mathrm{Cu}(2)(4)]^{+}$. Before using anchoring ligand 2 in the 'surface-as-ligand', 'surface-as-complex' protocol (Scheme 4), it was important to establish whether the bulky 6,6'-substituents in the bpy domain have an influence on the rate of ligand exchange.

The ${ }^{1} \mathrm{H}$ NMR spectra of $\mathrm{CD}_{2} \mathrm{Cl}_{2}$ solutions of the homoleptic complexes $\left[\mathrm{Cu}(3)_{2}\right]\left[\mathrm{PF}_{6}\right]$ and $\left[\mathrm{Cu}(4)_{2}\right]\left[\mathrm{PF}_{6}\right]^{16}$ are shown in Fig. 1a and $b$, respectively. The most diagnostic signals are those for protons $\mathrm{H}^{\mathrm{A} 3}\left(\delta \quad 8.40 \mathrm{ppm}\right.$ in $\left[\mathrm{Cu}(3)_{2}\right]\left[\mathrm{PF}_{6}\right], \delta$ 8.12 $\mathrm{ppm}$ in $\left[\mathrm{Cu}(4)_{2}\right]\left[\mathrm{PF}_{6}\right]$, see Scheme 2) and the signal at $\delta 2.37 \mathrm{pm}$ for $\mathrm{H}^{\mathrm{Me}}$ in $\left[\mathrm{Cu}(3)_{2}\right]\left[\mathrm{PF}_{6}\right]$. (Note that the chemical shift of the $\mathrm{H}^{\mathrm{A} 3}$ signal is sensitive to solvent. $\left.{ }^{16}\right)$ A $1: 1$ mixture of $\left[\mathrm{Cu}(3)_{2}\right]\left[\mathrm{PF}_{6}\right]$ and $\left[\mathrm{Cu}(4)_{2}\right]\left[\mathrm{PF}_{6}\right]$ in $\mathrm{CD}_{2} \mathrm{Cl}_{2}$ was prepared in an NMR tube and the ${ }^{1} \mathrm{H}$ NMR spectrum (Fig. 1c) recorded immediately. The appearance of four new signals arising from the $\mathrm{H}^{\mathrm{A} 3}$ and $\mathrm{H}^{\mathrm{A} 5}$ protons $(\delta 8.61$, 8.03, 7.91 and $7.37 \mathrm{ppm}$ ) and a new signal at $\delta 2.15 \mathrm{ppm}$ showed unambiguously that ligand exchange occurred; the relative integrals (Fig. $\mathrm{S} 1 \dagger$ ) of the signals were consistent with a statistical (1:2:1) mixture of $\left[\mathrm{Cu}(3)_{2}\right]\left[\mathrm{PF}_{6}\right][\mathrm{Cu}(3)(4)]\left[\mathrm{PF}_{6}\right]$ and $\left[\mathrm{Cu}(4)_{2}\right]\left[\mathrm{PF}_{6}\right]$. The spectrum of the mixture was recorded after 24 hours and showed no changes from that shown in Fig. 1c confirming that equilibration is reached immediately after the homoleptic complexes are mixed.

\section{Model dyes with anchoring ligand 2}

The first investigation with the new anchoring ligand 2 was with $\mathrm{TiO}_{2}$-supported model dyes $[\mathrm{Cu}(2)(\mathrm{bpy})]^{+},[\mathrm{Cu}(2)(6-\mathrm{Mebpy})]^{+}$and $\left[\mathrm{Cu}(2)\left(6,6^{\prime}-\mathrm{Me}_{2} \mathrm{bpy}\right)\right]^{+}$. The aim was to assess whether $6,6^{\prime}-$ substituents in the ancillary ligand remain important when the anchoring ligand contains phenyl substituents in the 6,6'-positions. Electrodes with the three dyes were assembled by first dipping the electrode into a DMSO solution of 2 followed by immersion in a second dye-bath containing a $\mathrm{CH}_{2} \mathrm{Cl}_{2}$ solution of $\left[\mathrm{Cu}(6-\mathrm{Mebpy})_{2}\right]\left[\mathrm{PF}_{6}\right]$ or $\left[\mathrm{Cu}\left(6,6^{\prime}-\mathrm{Me}_{2} \mathrm{bpy}\right)_{2}\right]\left[\mathrm{PF}_{6}\right]$, or a $\mathrm{CH}_{2} \mathrm{Cl}_{2}$ solution containing a $1: 2$ ratio of $\left[\mathrm{Cu}(\mathrm{NCMe})_{4}\right]\left[\mathrm{PF}_{6}\right]$ and bpy. These photoanodes were incorporated into sealed and masked DSCs, and it was noted that the colour of the dye partially bleached as electrolyte was added to the DSC. We return to this later.

A set of electrodes without a scattering layer was assembled to record the solid-state electronic spectra of the surface-bound dyes $[\mathrm{Cu}(2)(\mathrm{bpy})]^{+},[\mathrm{Cu}(2)(6-\mathrm{Mebpy})]^{+}$and $\left[\mathrm{Cu}(2)\left(6,6^{\prime}-\mathrm{Me}_{2} \text { bpy }\right)\right]^{+}$. The spectra are compared with that of $\left[\mathrm{Cu}(\mathbf{1})\left(6,6^{\prime}-\mathrm{Me}_{2} \mathrm{bpy}\right)\right]^{+}$in Fig. 2. As anticipated, the three dyes containing anchor 2 show

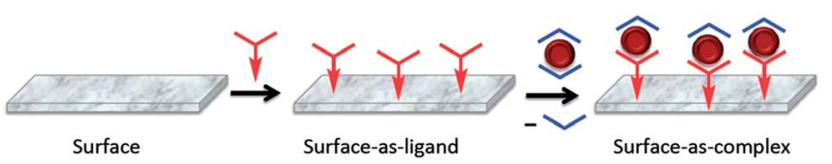

Scheme 4 'Surface-as-ligand', 'surface-as-complex' approach to stepwise assembly of heteroleptic copper(I) dyes by on-surface exchange between an anchoring ligand (red) and ancillary ligand (blue) via reaction of the functionalized surface with a homoleptic copper(।) complex. 


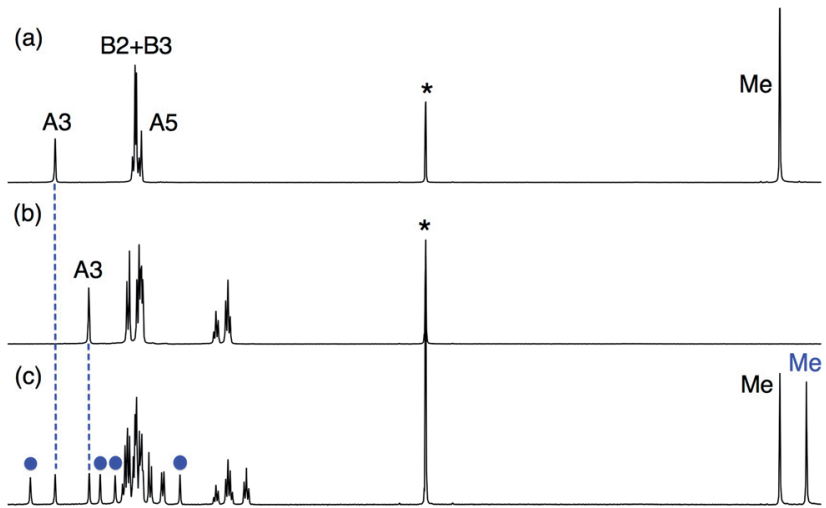

\begin{tabular}{llllllllllllllllll}
\hline 8.6 & 8.2 & 7.8 & 7.4 & 7.0 & 6.6 & 6.2 & 5.8 & 5.4 & 5.0 & 4.6 & 4.2 & 3.8 & 3.4 & 3.0 & 2.6 & 2.2
\end{tabular}

Fig. $1500 \mathrm{MHz}{ }^{1} \mathrm{H}$ NMR spectra of $\mathrm{CD}_{2} \mathrm{Cl}_{2}$ solutions of (a) $\left[\mathrm{Cu}(3)_{2}\right]\left[\mathrm{PF}_{6}\right],(\mathrm{b})\left[\mathrm{Cu}(4)_{2}\right]\left[\mathrm{PF}_{6}\right]$, and (c) a $1: 1$ mixture of $\left[\mathrm{Cu}(3)_{2}\right]\left[\mathrm{PF}_{6}\right]$ and $\left[\mathrm{Cu}(4)_{2}\right]\left[\mathrm{PF}_{6}\right]$ with signals assigned to the $\mathrm{H}^{\mathrm{A} 3}$ and $\mathrm{H}^{\mathrm{A} 5}$ and Me protons in $[\mathrm{Cu}(3)(4)]\left[\mathrm{PF}_{6}\right]$ highlighted in blue. The signal marked $*$ is residual $\mathrm{CDHCl}_{2}$. Chemical shifts are in $\delta / \mathrm{ppm}$.

extended absorption towards the red end of the spectrum. This is highly desirable since enhancement of photon harvesting at lower energies is still greatly lacking in copper(I) dyes ${ }^{9,18,28}$ reported to date.

The performance parameters for the DSCs with $[\mathrm{Cu}(2)(\mathrm{bpy})]^{+}$, $[\mathrm{Cu}(2)(6-\mathrm{Mebpy})]^{+}$and $\left[\mathrm{Cu}(2)\left(6,6^{\prime}-\mathrm{Me}_{2} \mathrm{bpy}\right)\right]^{+}$are given in Table 1 , and $J-V$ curves and EQE spectra are shown in Fig. 3 and 4. All DSCs show an aging effect after one day with enhanced opencircuit voltage $\left(V_{\mathrm{OC}}\right)$, short-circuit current density $\left(J_{\mathrm{sC}}\right)$ and efficiency $(\eta)$. This phenomenon is common for n-type DSCs containing bis(diimine)copper(I) dyes with $\mathrm{I}^{-} / \mathrm{I}_{3}{ }^{-}$electrolyte; ${ }^{8,15,16,22}$ it is also observed for some ruthenium(II) dyes and is attributed to reorganization of the initially aggregated dye molecules on the semiconductor surface. ${ }^{29-31}$ With bpy as the ancillary ligand, the DSCs perform very poorly, while those with 6-Mebpy or 6,6'$\mathrm{Me}_{2}$ bpy reach efficiencies relative to $\mathrm{N} 719$ of $\approx 10 \%$ and $\approx 13 \%$ immediately and one day, respectively, after sealing the cells.

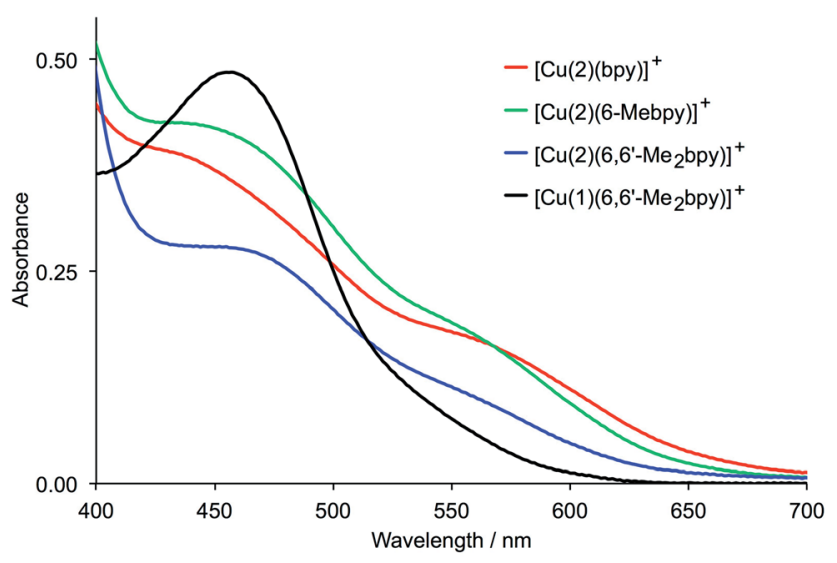

Fig. 2 Solid-state absorption spectra (transmission mode) of electrodes functionalized with dyes $[\mathrm{Cu}(2)(\mathrm{bpy})]^{+},[\mathrm{Cu}(2)(6-\mathrm{Mebpy})]^{+}$, $\left[\mathrm{Cu}(2)\left(6,6^{\prime}-\mathrm{Me}_{2} \mathrm{bpy}\right)\right]^{+}$and $\left[\mathrm{Cu}(1)\left(6,6^{\prime}-\mathrm{Me}_{2} \mathrm{bpy}\right)\right]^{+}$.
Values of $V_{\mathrm{OC}}$ and of $J_{\mathrm{SC}}$ are similar (Table 1 and Fig. 3) for DSCs containing $[\mathrm{Cu}(2)(6-\mathrm{Mebpy})]^{+}$and $\left[\mathrm{Cu}(2)\left(6,6^{\prime}-\mathrm{Me}_{2} \mathrm{bpy}\right)\right]^{+}$, but are significantly less than for $\left[\mathrm{Cu}(\mathbf{1})\left(6,6^{\prime}-\mathrm{Me}_{2} \mathrm{bpy}\right)\right]^{+}(\text {Table } 1)^{20}$ for which DSC parameters were measured under the same conditions and using the same sun simulator as in the current work. The EQE spectra in Fig. 4 confirm enhanced electron injection for $[\mathrm{Cu}(2)(6-\mathrm{Mebpy})]^{+}$and $\left[\mathrm{Cu}(2)\left(6,6^{\prime}-\mathrm{Me}_{2} \mathrm{bpy}\right)\right]^{+}$compared to $[\mathrm{Cu}(2)(\text { bpy })]^{+}$. However, the maximum $\mathrm{EQE}($ at $\lambda \approx 490 \mathrm{~nm}$ ) of $\approx 17 \%$ for these dyes is notably lower than for $\left[\mathrm{Cu}(1)\left(6,6^{\prime}-\right.\right.$ $\left.\left.\mathrm{Me}_{2} \mathrm{bpy}\right)\right]^{+}\left(\mathrm{EQE}_{\max }=41.7 \%\right.$ at $\left.\lambda \approx 470 \mathrm{~nm}\right) .{ }^{20}$ An important feature of the EQE spectra of DSCs containing $[\mathrm{Cu}(2)(6-\mathrm{Mebpy})]^{+}$ and $\left[\mathrm{Cu}(2)\left(6,6^{\prime}-\mathrm{Me}_{2} \text { bpy }\right)\right]^{+}$is the broad shoulder at $\approx 580 \mathrm{~nm}$. This demonstrates enhanced electron injection to lower energy compared to dyes containing anchoring ligand $\mathbf{1}$. We propose that the poorer performance of DSCs with dyes $[\mathrm{Cu}(2)(6-$ Mebpy $)]^{+}$and $\left[\mathrm{Cu}(2)\left(6,6^{\prime}-\mathrm{Me}_{2} \mathrm{bpy}\right)\right]^{+}$versus $\left[\mathrm{Cu}(\mathbf{1})\left(6,6^{\prime}-\mathrm{Me}_{2} \mathrm{bpy}\right)\right]^{+}$ is associated either with the bleaching effect (see later) and/or with a lower coverage of anchoring ligand 2 in the first dyebath cycle. The data also suggest that the ancillary ligand in $\left[\mathrm{Cu}(2)\left(\mathrm{L}_{\text {ancillary }}\right)\right]^{+}$should bear at least one substituent in the 6position of the bpy domain.

\section{Dyes combining anchors 1 and 2 with ancillary ligands 3 and 4}

Electrodes with $\mathrm{TiO}_{2}$-bound dyes $[\mathrm{Cu}(\mathbf{1})(\mathbf{3})]^{+}, \quad[\mathrm{Cu}(\mathbf{1})(\mathbf{4})]^{+}$, $[\mathrm{Cu}(2)(3)]^{+}$and $[\mathrm{Cu}(2)(4)]^{+}$(Scheme 5) were prepared using the strategy in Scheme 4. The dye-functionalized electrodes were incorporated into sealed and masked DSCs, and cell characteristics are given in Table 2. We have reported DSC parameters for the dyes $[\mathrm{Cu}(\mathbf{1})(\mathbf{3})]^{+}$and $[\mathrm{Cu}(\mathbf{1})(\mathbf{4})]$ in previous work. ${ }^{\mathbf{8}, 16}$ However, direct comparison of values of $J_{\mathrm{SC}}, V_{\mathrm{OC}}$ and $\eta$ are difficult because of the use of different sun simulators (SolarSim 150 and LOT Quantum Design LS0811). To overcome this, ${ }^{20}$ we routinely report efficiencies relative to that of N719 set at $100 \%$. The relative $\eta$ values for $[\mathrm{Cu}(\mathbf{1})(3)]^{+}$and $[\mathrm{Cu}(\mathbf{1})(\mathbf{4})]^{+}$in the present work (Table 1) are comparable with our previous measurements, ${ }^{8,16}$ confirming the reproducibility of dye performances between different batches of DSCs.

Table 1 Performance parameters of masked DSCs with [Cu(2)(bpy)] $]^{+}$, $[\mathrm{Cu}(2)(6-\mathrm{Mebpy})]^{+}$and $\left[\mathrm{Cu}(2)\left(6,6^{\prime}-\mathrm{Me}_{2} \mathrm{bpy}\right)\right]^{+}$; data are compared to a DSC containing N719

\begin{tabular}{lccccc}
\hline $\begin{array}{l}J_{\mathrm{SC}} / \\
\mathrm{mA} \mathrm{cm}\end{array}$ & $\begin{array}{l}V_{\mathrm{OC}} / \\
\mathrm{mV}\end{array}$ & $\begin{array}{l}\mathrm{ff} / \\
\%\end{array}$ & $\begin{array}{l}\eta / \\
\%\end{array}$ & $\begin{array}{l}\text { Relative } \\
\eta / \%\end{array}$ \\
\hline Dye & & & & & \\
On the day of sealing the DSC & & & & \\
{$[\mathrm{Cu}(2)(\mathrm{bpy})]^{+}$} & 0.15 & 285 & 55.9 & 0.02 & 0.3 \\
{$[\mathrm{Cu}(2)(6-\mathrm{Mebpy})]^{+}$} & 1.71 & 499 & 74.1 & 0.63 & 10.7 \\
{$\left[\mathrm{Cu}(2)\left(6,6^{\prime}-\mathrm{Me}_{2} \mathrm{bpy}\right)\right]^{+}$} & 1.66 & 486 & 72.8 & 0.59 & 10.0 \\
{$\left[\mathrm{Cu}(\mathbf{1})\left(6,6^{\prime}-\mathrm{Me}_{2} \mathrm{bpy}\right)\right]^{+a}$} & 3.79 & 522 & 73.8 & 1.46 & 24.7 \\
$\mathrm{~N} 719$ & 12.51 & 672 & 70.2 & 5.91 & 100
\end{tabular}

1 day after sealing the DSC

$\begin{array}{lrrrrr}{[\mathrm{Cu}(2)(\text { bpy })]^{+}} & 0.42 & 379 & 58.9 & 0.09 & 1.5 \\ {[\mathrm{Cu}(2)(6-\mathrm{Mebpy})]^{+}} & 2.02 & 533 & 74.4 & 0.80 & 13.5 \\ {\left[\mathrm{Cu}(2)\left(6,6^{\prime}-\mathrm{Me}_{2} \text { bpy }\right)\right]^{+}} & 1.90 & 529 & 73.5 & 0.74 & 12.5\end{array}$

${ }^{a}$ Data from ref. 20. 

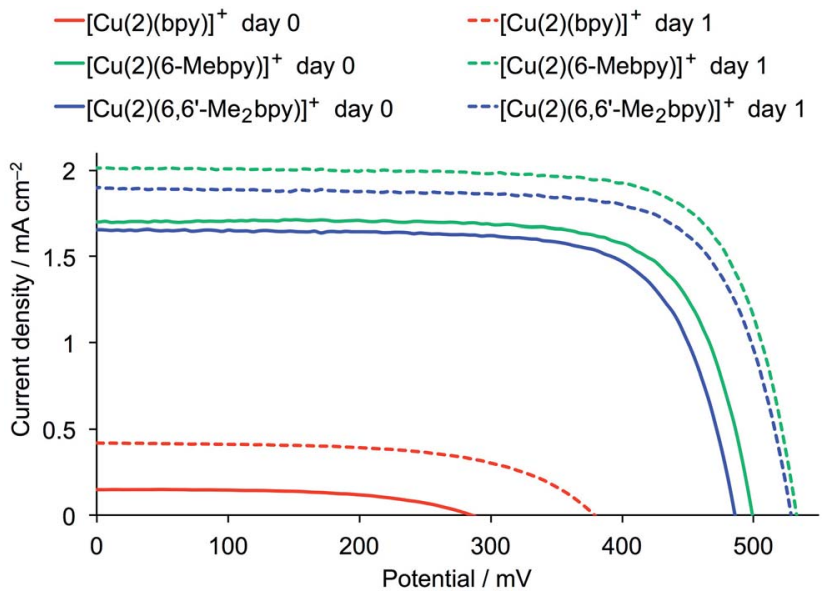

Fig. $3 \mathrm{~J}-V$ curves for DSCs with the dyes $[\mathrm{Cu}(2)(\mathrm{bpy})]^{+},[\mathrm{Cu}(2)(6-$ Mebpy) $]^{+}$and $\left[\mathrm{Cu}(2)\left(6,6^{\prime}-\mathrm{Me}_{2} \mathrm{bpy}\right)\right]^{+}$measured on the day of sealing the DSC and one day later.

$J-V$ curves recorded on the day of DSC fabrication are shown in Fig. 5 and 6 displays EQE spectra for the same cells. Irrespective of the ancillary ligand, performances of the dyes containing anchor $\mathbf{2}$ are poor in comparison to those with anchor $\mathbf{1}$, and performances worsen with time. Consistent with results for the model dyes containing anchor 2, the EQE spectra confirm electron injection towards the red-end of the spectrum for $[\mathrm{Cu}(2)(3)]^{+}$and $[\mathrm{Cu}(2)(4)]^{+}$which is absent for $[\mathrm{Cu}(\mathbf{1})(3)]^{+}$and $[\mathrm{Cu}(\mathbf{1})(\mathbf{4})]^{+}$. However, $\mathrm{EQE}_{\max }$ values of $47.2 \%$ (at $\lambda=480 \mathrm{~nm}$ ) for $[\mathrm{Cu}(\mathbf{1})(\mathbf{3})]^{+}$and $[\mathrm{Cu}(\mathbf{1})(\mathbf{4})]^{+}$far surpass those of $[\mathrm{Cu}(2)(3)]^{+}$and $[\mathrm{Cu}(2)(4)]^{+}\left(\mathrm{EQE}_{\max }=12.2 \%\right.$ at $\lambda=500 \mathrm{~nm}$ and $8.4 \%$ at $\lambda=570$ $\mathrm{nm}$ for $[\mathrm{Cu}(2)(3)]^{+} ; \mathrm{EQE}_{\max }=5.4 \%$ at $\lambda=500 \mathrm{~nm}$ and $3.9 \%$ at $\lambda=580 \mathrm{~nm}$ for $\left.[\mathrm{Cu}(2)(4)]^{+}\right)$. Low values of both $J_{\mathrm{SC}}$ and $V_{\mathrm{OC}}$ (Fig. 5) contribute to the poor overall efficiencies of DSCs containing $[\mathrm{Cu}(2)(3)]^{+}$and $[\mathrm{Cu}(2)(4)]^{+}$.

The poor performance of dyes with anchor 2 is associated with bleaching of the dye once $\mathrm{I}^{-} / \mathrm{I}_{3}{ }^{-}$electrolyte is added to the DSC. Solid-state absorption spectra of electrodes (without a

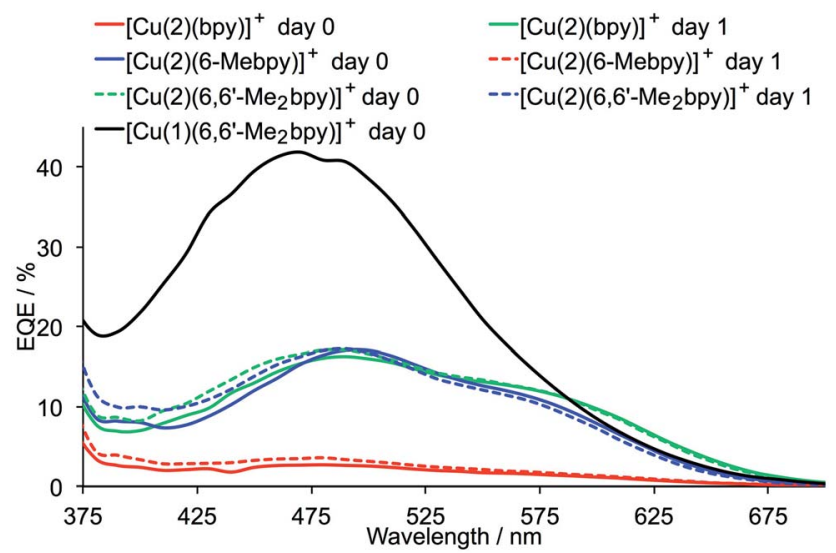

Fig. 4 EQE spectra for DSCs with the dyes $[\mathrm{Cu}(2)(\mathrm{bpy})]^{+},[\mathrm{Cu}(2)(6-$ Mebpy) $]^{+}$and $\left[\mathrm{Cu}(2)\left(6,6^{\prime}-\mathrm{Me}_{2} \mathrm{bpy}\right)\right]^{+}$measured on the day of sealing the cell and one day later, and with $\left[\mathrm{Cu}(1)\left(6,6^{\prime}-\mathrm{Me}_{2} \mathrm{bpy}\right)\right]^{+}$measured on the day of sealing.
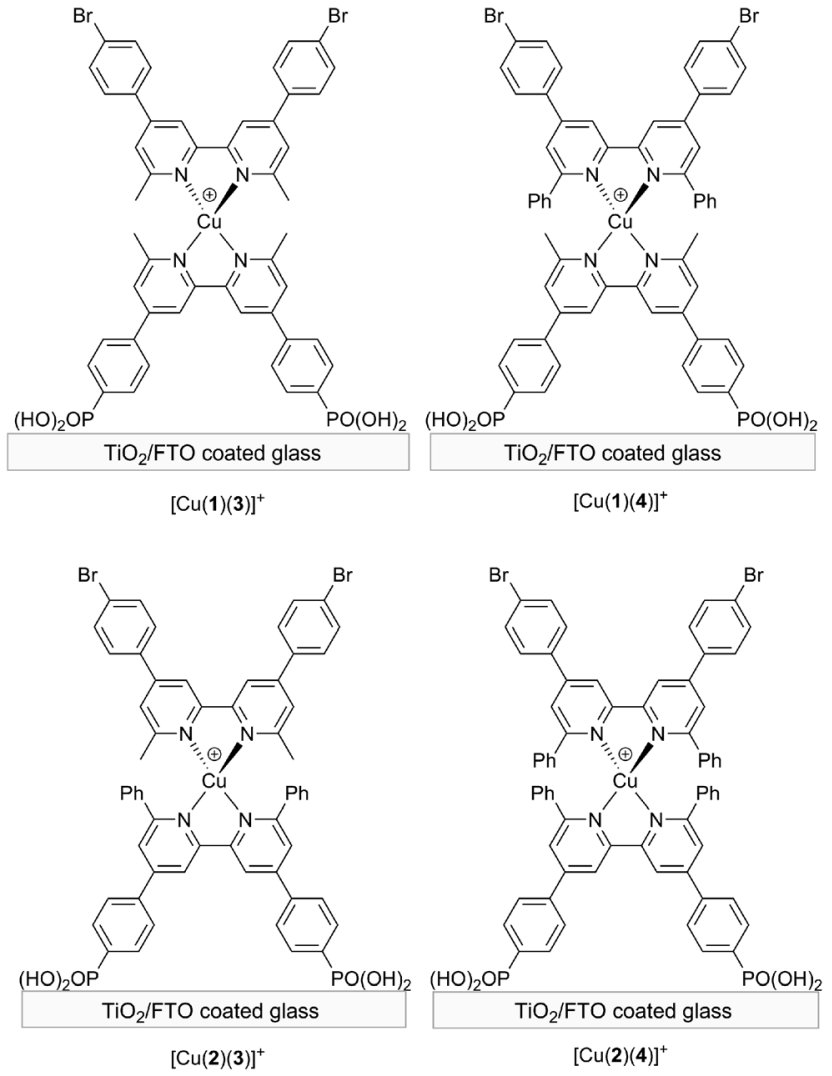

Scheme 5 Surface-assembled heteroleptic dyes.

scattering layer) with adsorbed $[\mathrm{Cu}(\mathbf{1})(3)]^{+}\left(\lambda_{\max }=475 \mathrm{~nm}\right)$, $[\mathrm{Cu}(1)(4)]^{+}\left(\lambda_{\max }=490 \mathrm{~nm}\right),[\mathrm{Cu}(2)(3)]^{+}\left(\lambda_{\max }=482 \mathrm{~nm}\right)$ and $[\mathrm{Cu}(2)(4)]^{+}\left(\lambda_{\max }=505,570 \mathrm{~nm}\right)$ are shown in Fig. 7; Fig. 8a shows photographs of the electrodes. In $[\mathrm{Cu}(\mathbf{1})(\mathbf{4})]^{+}$and $[\mathrm{Cu}(2)(3)]^{+}$, the copper(I) centre has the same coordination environment (Scheme 5) and the spectra of these adsorbed dyes exhibit similar absorption maxima (Fig. 7). These are redshifted with respect to that of $[\mathrm{Cu}(\mathbf{1})(3)]^{+}$, and additional red-

Table 2 Performance parameters of masked DSCs with dyes $[\mathrm{Cu}(1)(3)]^{+},[\mathrm{Cu}(1)(4)]^{+},[\mathrm{Cu}(2)(3)]^{+}$and $[\mathrm{Cu}(2)(4)]^{+}$(see Scheme 5); data are compared to a DSC with dye N719

\begin{tabular}{lccccc}
\hline Dye & $\begin{array}{l}J_{\mathrm{SC}} / \\
\mathrm{mA} \mathrm{cm}{ }^{-2}\end{array}$ & $\begin{array}{l}V_{\mathrm{OC}} / \\
\mathrm{mV}\end{array}$ & $\begin{array}{l}\mathrm{ff} / \\
\%\end{array}$ & $\begin{array}{l}\eta / \\
\%\end{array}$ & $\begin{array}{l}\text { Relative } \\
\eta / \%\end{array}$ \\
\hline \multicolumn{7}{l}{ On the day of sealing the DSC } \\
{$[\mathrm{Cu}(\mathbf{1})(3)]^{+}$} & 4.92 & 554 & 71.7 & 1.95 & 33.0 \\
{$[\mathrm{Cu}(\mathbf{1})(\mathbf{4})]^{+}$} & 4.63 & 550 & 74.3 & 1.89 & 32.0 \\
{$[\mathrm{Cu}(2)(3)]^{+}$} & 1.60 & 496 & 74.2 & 0.59 & 10.0 \\
{$[\mathrm{Cu}(2)(4)]^{+}$} & 1.00 & 463 & 72.4 & 0.33 & 5.6 \\
$\mathrm{~N} 719$ & 12.51 & 672 & 70.2 & 5.91 & 100
\end{tabular}

1 day after sealing the DSC

$\begin{array}{lllllr}{[\mathrm{Cu}(\mathbf{1})(3)]^{+}} & 4.86 & 585 & 71.8 & 2.04 & 34.5 \\ {[\mathrm{Cu}(\mathbf{1})(\mathbf{4})]^{+}} & 4.28 & 576 & 74.4 & 1.83 & 31.0 \\ {[\mathrm{Cu}(2)(3)]^{+}} & 1.10 & 503 & 73.6 & 0.41 & 6.9 \\ {[\mathrm{Cu}(2)(4)]^{+}} & 0.62 & 472 & 71.1 & 0.21 & 3.6\end{array}$




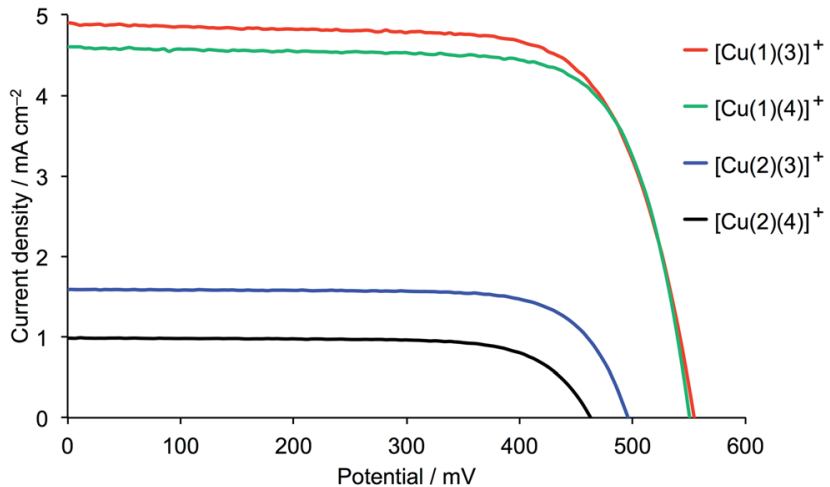

Fig. $5 \mathrm{~J}-V$ curves for DSCs with the dyes $[\mathrm{Cu}(1)(3)]^{+},[\mathrm{Cu}(1)(4)]^{+}$, $[\mathrm{Cu}(2)(3)]^{+}$and $[\mathrm{Cu}(2)(4)]^{+}$(see Scheme 5) measured on the day of sealing the DSCs.

shifting and the appearance of two absorption maxima are observed on going to $[\mathrm{Cu}(2)(4)]^{+}$. The latter is consistent with a flattening of the tetrahedral coordination sphere; analogous features are observed in the solution absorption spectrum of $\left[\mathrm{Cu}(\mathbf{4})_{2}\right]^{+}{ }^{16}$ and $\left[\mathrm{Cu}(\mathrm{dpp})_{2}\right]^{+}$(dpp = 2,9-diphenyl-1,10-phenanthroline). ${ }^{32}$ These spectroscopic changes auger well for enhanced photon harvesting, but once dye-functionalized photoanodes are exposed to the $\mathrm{I}^{-} / \mathrm{I}_{3}{ }^{-}$electrolyte in DSCs, bleaching of dyes with anchor 2 occurs (Fig. 8); this mimics the behaviour of the model dyes described above.

Dye bleaching was quantified by recording the solid-state absorption spectra of an electrode functionalized with $[\mathrm{Cu}(2)(3)]^{+}$before and after exposure to $\mathrm{I}^{-} / \mathrm{I}_{3}{ }^{-}$electrolyte (Fig. 9 , solid-blue to red curves). A similar effect was observed when an analogous electrode was treated with a solution of LiI in 3methoxypropionitrile (Fig. 9, hashed-blue to red curves). The results suggest that bleaching is caused by attack at the copper(I) centre by iodide ion. However, an important finding is that the on-surface dye is readily regenerated by soaking the bleached electrode in either an $\mathrm{CH}_{2} \mathrm{Cl}_{2}$ solution of the ancillary ligand 3 or in an $\mathrm{MeCN}$ solution of $\left[\mathrm{Cu}(\mathrm{NCMe})_{4}\right]\left[\mathrm{PF}_{6}\right]$ followed by a solution of $\mathrm{CH}_{2} \mathrm{Cl}_{2}$ solution of 3 (Fig. 9, red to green curves).

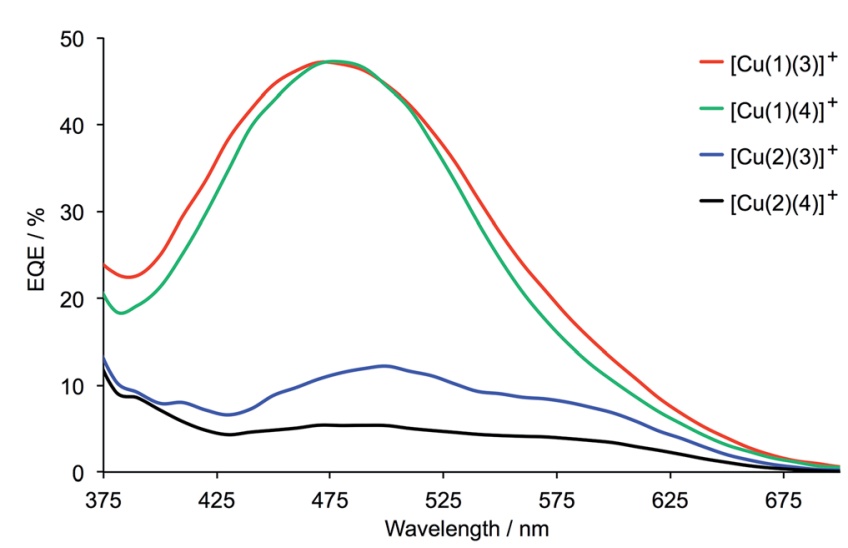

Fig. 6 EQE spectra for DSCs with the dyes $[\mathrm{Cu}(1)(3)]^{+},[\mathrm{Cu}(1)(4)]^{+}$, $[\mathrm{Cu}(2)(3)]^{+}$and $[\mathrm{Cu}(2)(4)]^{+}$measured on the day of sealing the DSCs.

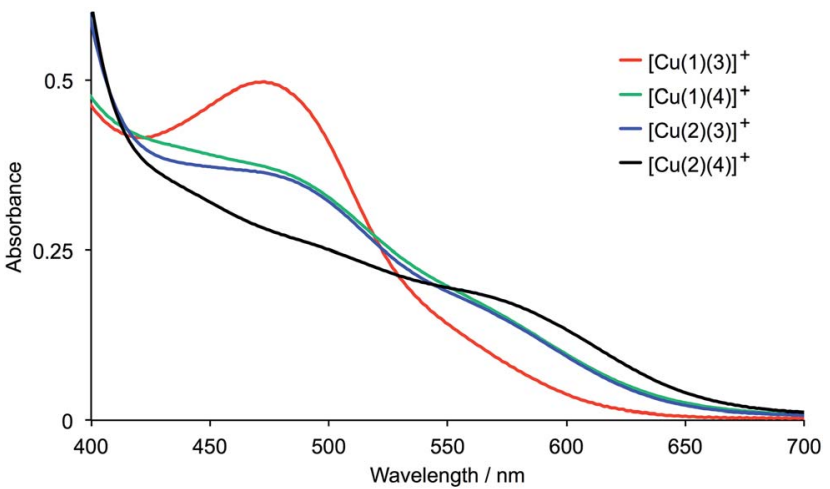

Fig. 7 Solid-state absorption spectra (transmission mode) of electrodes functionalized with dyes $[\mathrm{Cu}(1)(3)]^{+},[\mathrm{Cu}(1)(4)]^{+},[\mathrm{Cu}(2)(3)]^{+}$and $[\mathrm{Cu}(2)(4)]^{+}$

The copper(I) centre in $[\mathrm{Cu}(2)(4)]^{+}$(Scheme 5) is expected to possess a distorted tetrahedral coordination sphere, flattened as a consequence of inter-ligand $\pi$-stacking interactions as confirmed in the solid-state structures of $\left[\mathrm{Cu}(4)_{2}\right]^{+}$(Fig. 10a) ${ }^{16}$ and $\left[\mathrm{Cu}(\mathrm{dpp})_{2}\right]^{+} .{ }^{32}$ It is noteworthy that the solution absorption spectrum of $\left[\mathrm{Cu}(\mathrm{dpp})_{2}\right]^{+}$is independent of solvent (MeCN, $\left.\mathrm{MeCN} / \mathrm{H}_{2} \mathrm{O}, \mathrm{CH}_{2} \mathrm{Cl}_{2}\right),{ }^{32}$ implying that coordinating solvents do not enter the copper(I) coordination sphere. Going from dpp to ligands 1-4 involves a change from a rigid phen backbone to a bpy unit that, even when chelated, can undergo significant torsional deformation. ${ }^{33}$ We suggest that this is a contributing factor towards the sensitivity of $[\mathrm{Cu}(2)(4)]^{+}$towards iodide ion. Finally, while both $[\mathrm{Cu}(\mathbf{1})(\mathbf{4})]^{+}$and $[\mathrm{Cu}(2)(3)]^{+}$contain identical local copper(I) coordination environments (Fig. 10b), only DSCs containing $[\mathrm{Cu}(2)(3)]^{+}$bleach in the presence of $\mathrm{I}^{-}$. This suggests that 6- and 6'-phenyl substituents in the ancillary ligand help to protect the copper(I) centre; in contrast, placing them in the anchoring domain renders the dye susceptible to attack by $\mathrm{I}^{-}$. We are currently extending these studies to other dyes containing anchor 2 .

(a)
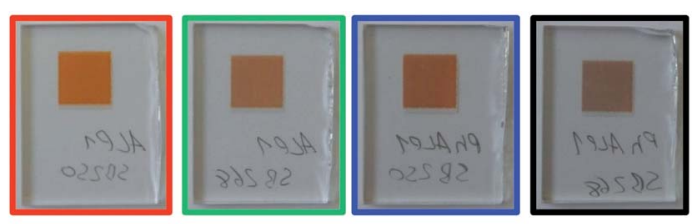

(b)
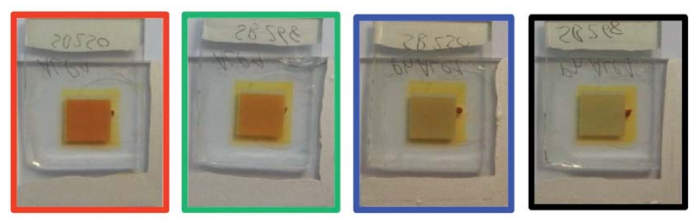

$[\mathrm{Cu}(1)(3)]^{+}[\mathrm{Cu}(1)(4)]^{+} \quad[\mathrm{Cu}(2)(3)]^{+}[\mathrm{Cu}(2)(4)]^{+}$

Fig. 8 (a) Dye-functionalized electrodes used for solid-state UV-vis measurements (Fig. 7) with (left to right) $[\mathrm{Cu}(1)(3)]^{+},[\mathrm{Cu}(1)(4)]^{+}$, $[\mathrm{Cu}(2)(3)]^{+}$and $[\mathrm{Cu}(2)(4)]^{+}$. (b) DSCs after filling with $\mathrm{I}^{-} / \mathrm{I}_{3}^{-}$electrolyte and sealing. The coloured borders correspond to the colours used in Fig. 7. 


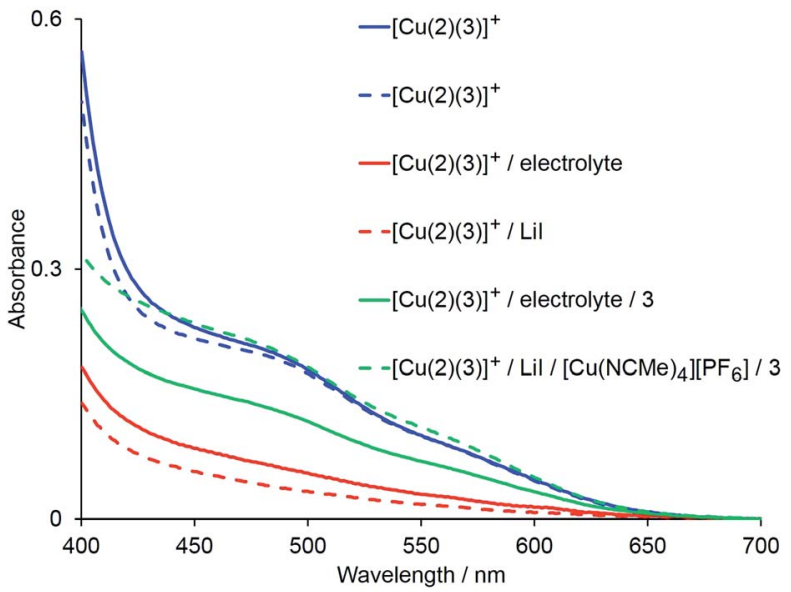

Fig. 9 Solid-state absorption spectra (transmission mode) of electrodes functionalized with dye $[\mathrm{Cu}(2)(3)]^{+}$(duplicate electrodes, blue), after treatment with $\mathrm{I}^{-} / \mathrm{I}_{3}^{-}$electrolyte or Lil solutions (red), and after dye regeneration (green).

\section{Effect of a co-adsorbant on DSCs with $[\mathrm{Cu}(2)(3)]^{+}$}

The addition of a co-adsorbant such as cheno can significantly enhance the DSC performance of bis(diimine)copper(I) dyes, particularly those with sterically demanding ligands. ${ }^{9,35} \mathrm{We}$ therefore investigated whether the performance of $[\mathrm{Cu}(2)(3)]^{+}$ (Scheme 5) could be improved by addition of cheno. The coadsorbant was added in the second step of the on-surface dye assembly (Scheme 4) because we have previously shown that competitive binding of cheno and anchoring ligand may occur if cheno is introduced in the first soaking cycle. ${ }^{35}$ The second dye-bath comprised a $1: 1$ mixture of cheno and $\left[\mathrm{Cu}(3)_{2}\right]\left[\mathrm{PF}_{6}\right]$. Performance parameters for the DSCs with and without coadsorbant are compared in Table 3. The addition of cheno leads to a significant gain in both $J_{\mathrm{SC}}$ and $V_{\mathrm{OC}}$ (Fig. 11) and an overall increase in DSC conversion efficiency (0.59 to $0.97 \%$ ). However, the efficiency remains less than half that of the dye $[\mathrm{Cu}(\mathbf{1})(3)]^{+}$(Scheme 5). The increase in $J_{\mathrm{SC}}$ is confirmed in the EQE spectra (Fig. 12) which show that the presence of cheno

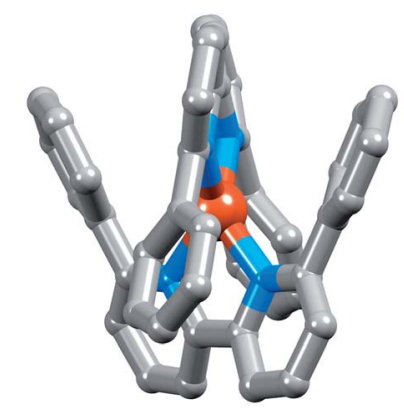

(a)

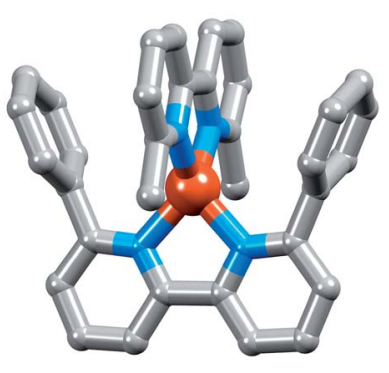

(b)
Fig. 10 (a) The $\left\{\mathrm{Cu}\left(6,6^{\prime}-\mathrm{Ph}_{2} \mathrm{bpy}\right)_{2}\right\}$ coordination sphere expected in $[\mathrm{Cu}(2)(4)]^{+}$based on the solid-state structure of $\left[\mathrm{Cu}(4)_{2}\right]^{+} .{ }^{16}$ (b) Modelled coordination sphere in $[\mathrm{Cu}(2)(3)]^{+}$and $[\mathrm{Cu}(1)(4)]^{+}$; the structure has been modelled using molecular mechanics at the MMFF level with Spartan 14 (v. 1.1.8). ${ }^{34}$
Table 3 Performance data for masked DSCs with dye $[\mathrm{Cu}(2)(3)]^{+}$ (Scheme 5) with and without co-adsorbant cheno; data are compared to a DSC with dye N719. Data for DSCs without cheno are taken from Table 2

\begin{tabular}{lccccc}
\hline $\begin{array}{l}J_{\mathrm{SC}} / \\
\mathrm{mA} \mathrm{cm}\end{array}$ & $\begin{array}{l}V_{\mathrm{OC}} / \\
\mathrm{mV}\end{array}$ & $\begin{array}{l}\mathrm{ff} / \\
\%\end{array}$ & $\begin{array}{l}\eta / \\
\%\end{array}$ & $\begin{array}{l}\text { Relative } \\
\eta / \%\end{array}$ \\
\hline $\begin{array}{l}\text { On the day of sealing the DSC } \\
{[\mathrm{Cu}(2)(3)]^{+}}\end{array}$ & 1.60 & 496 & 74.2 & 0.59 & 10.0 \\
{$[\mathrm{Cu}(2)(3)]^{+} /$cheno } & 2.54 & 520 & 73.4 & 0.97 & 16.4 \\
$\mathrm{~N} 719$ & 12.51 & 672 & 70.2 & 5.91 & 100 \\
& & & & & \\
$\mathbf{1}$ day after sealing the DSC & & & & \\
{$[\mathrm{Cu}(2)(3)]^{+}$} & 1.10 & 503 & 73.6 & 0.41 & 6.9 \\
{$[\mathrm{Cu}(2)(3)]^{+} /$cheno } & 2.10 & 539 & 72.3 & 0.82 & 13.9 \\
\hline
\end{tabular}

results in an increase in $\mathrm{EQE}_{\max }$ from $12.2 \%(\lambda=500 \mathrm{~nm})$ and $8.4 \%(\lambda=570 \mathrm{~nm})$, to $19.3 \%(\lambda=500 \mathrm{~nm})$ and $15.6 \%(\lambda=$ $570 \mathrm{~nm})$. However, one day-old DSCs had bleached with concomitant deterioration in performance (Fig. 11 and 12), in contrast to the stability over a week or more of other bis(diimine)copper(I)-containing DSCs..$^{\mathbf{8 1 6 , 1 8 , 3 5}}$

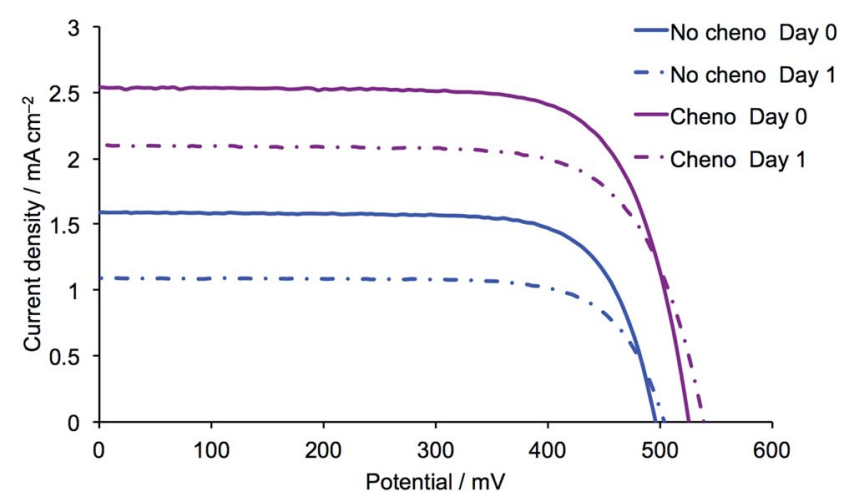

Fig. $11 J-V$ curves for DSCs with the dye $[\mathrm{Cu}(2)(3)]^{+}$(Scheme 5) with and without cheno, and measured on the day of sealing the DSC and one day later.

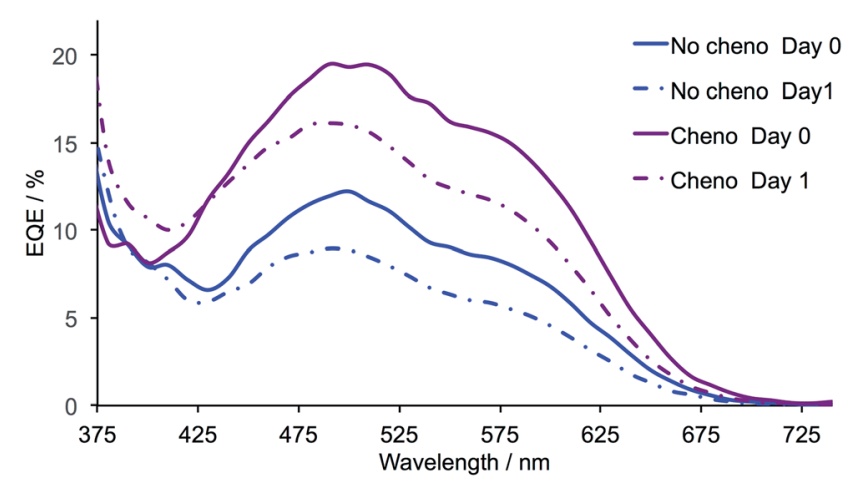

Fig. 12 EQE spectra for DSCs with the dye $[\mathrm{Cu}(2)(3)]^{+}$with and without cheno, and measured on the day of sealing the DSC and one day later. 


\section{Conclusions}

The effects of replacing the 6,6'-dimethyl substituents in phosphonic acid anchor $\mathbf{1}$ by phenyl substituents have been investigated; although we have shown 1 to be an efficient anchor in $\left[\mathrm{Cu}(\mathbf{1})\left(\mathrm{L}_{\text {ancillary }}\right)_{2}\right]^{+}$dyes, a change from $\mathrm{Me}$ to $\mathrm{Ph}$ substituents adjacent to the metal-binding sites enhances light absorption at lower energies. Comparison of values of $V_{\mathrm{OC}}, J_{\mathrm{SC}}, \eta$ and EQE spectra for DSCs with model dyes $[\mathrm{Cu}(2)(\mathrm{bpy})]^{+}$, $[\mathrm{Cu}(2)(6-\mathrm{Mebpy})]^{+}$and $\left[\mathrm{Cu}(2)\left(6,6^{\prime}-\mathrm{Me}_{2} \mathrm{bpy}\right)\right]^{+}$confirm that methyl-substituents in $\mathrm{L}_{\text {ancillary }}$ are beneficial, but all dyes perform poorly compared to $\left[\mathrm{Cu}(\mathbf{1})\left(6,6^{\prime}-\mathrm{Me}_{2} \mathrm{bpy}\right)\right]^{+}$. Device parameters for DSCs with dyes $[\mathrm{Cu}(\mathbf{1})(\mathbf{3})]^{+}, \quad[\mathrm{Cu}(\mathbf{1})(\mathbf{4})]^{+}$, $[\mathrm{Cu}(2)(3)]^{+}$and $[\mathrm{Cu}(2)(4)]^{+}$reveal that dyes with anchor 2 give relative conversion efficiencies $\leq 10 \%$ versus N719 set at $100 \%$; this is significantly lower than the performances of $[\mathrm{Cu}(\mathbf{1})(\mathbf{3})]^{+}$ and $[\mathrm{Cu}(\mathbf{1})(4)]^{+}$(relative $\eta=30$ to $34.5 \%$ ). The performance of $[\mathrm{Cu}(2)(3)]^{+}$can be improved by the addition of the co-adsorbant cheno. All dyes with anchor 2 bleach in the presence of $\mathrm{I}^{-} / \mathrm{I}_{3}{ }^{-}$ electrolyte and bleaching also occurs when the dyes are exposed to iodide ion. The cause of bleaching appears to be displacement of $\mathrm{L}_{\text {ancillary }}$ or stripping of copper from the surface-bound complex; anchored dyes are readily regenerated by soaking a bleached electrode in solutions of $\mathrm{L}_{\text {ancillary, }}$ or in solutions of $\left[\mathrm{Cu}(\mathrm{NCMe})_{4}\right]\left[\mathrm{PF}_{6}\right]$ followed by $\mathrm{L}_{\text {ancillary }}$. We are now exploring the generalities of these observations with anchoring ligand 2, and regeneration of surface-adsorbed dyes after dyes have bleached. The bleaching effects justify more vigorous investigations of alternative electrolytes such as the $\mathrm{Co}^{2+} / \mathrm{Co}^{3+}$ based systems to replace $\mathrm{I}^{-} / \mathrm{I}_{3}{ }^{-}$in copper(I)-based DSCs. ${ }^{17}$ Further development of copper(I) dyes must continue to address improved spectral response towards the red-end of the visible spectrum, and find ways of increasing the short-circuit current density which is currently significantly lower than for state-ofthe-art ruthenium(II) dyes such as N719.

\section{Acknowledgements}

We acknowledge the financial support of the European Research Council (Advanced Grant 267816 LiLo), the Swiss National Science Foundation (Grant 200020_144500 and as part of the NCCR Molecular Systems Engineering) and the University of Basel. We thank Dr Biljana Bozic-Weber for useful discussions.

\section{Notes and references}

1 B. Bozic-Weber, E. C. Constable and C. E. Housecroft, Coord. Chem. Rev., 2013, 257, 3089.

2 M. S. Lazorski and F. N. Castellano, Polyhedron, 2014, 82, 57. 3 G. C. Vougioukalakis, A. I. Philippopoulos, T. Stergiopoulos and P. Falaras, Coord. Chem. Rev., 2011, 255, 2602.

4 F. Dumur, Org. Electron., 2015, 21, 27.

5 R. D. Costa, E. Ortí, H. J. Bolink, F. Monti, G. Accorsi and N. Armaroli, Angew. Chem., Int. Ed., 2012, 51, 8178.

6 S. Keller, E. C. Constable, C. E. Housecroft, M. Neuburger, A. Prescimone, G. Longo, A. Pertegás, M. Sessolo and H. J. Bolink, Dalton Trans., 2014, 16593.
7 H. Ozawa, Y. Okuyama and H. Arakawa, ChemPhysChem, 2014, 15, 1201; A. Yella, H.-W. Lee, H. N. Tsao, C. Yi, A. K. Chandiran, M. K. Nazeeruddin, E. W.-G. Diau, C.-Y. Yeh, S. M. Zakeeruddin and M. Grätzel, Science, 2011, 334, 629; M. Zhang, Y. Wang, M. Xu, W. Ma, R. Li and P. Wang, Energy Environ. Sci., 2013, 6, 2944; K. Kakiage, Y. Aoyama, T. Yano, T. Otsuka, T. Kyomen, M. Unno and M. Hanaya, Chem. Commun., 2014, 50, 6379.

8 F. J. Malzner, S. Y. Brauchli, E. C. Constable, C. E. Housecroft and M. Neuburger, RSC Adv., 2014, 4, 48712.

9 M. Sandroni, L. Favereau, A. Planchat, H. Akdas-Kilig, N. Szuwarski, Y. Pellegrin, E. Blart, H. Le Bozec, M. Boujtita and F. Odobel, J. Mater. Chem. A, 2014, 2, 9944.

10 A. Hernandez Redondo, E. C. Constable and C. E. Housecroft, Chimia, 2009, 63, 205.

11 See for example: M. Schmittel and A. Ganz, Chem. Commun., 1997, 999; M. Schmittel, H. Ammon, V. Kalsani, A. Wiegrefe and C. Michel, Chem. Commun., 2002, 2566.

12 M. Sandroni, M. Kayanuma, A. Planchat, N. Szuwarski, E. Blart, Y. Pellegrin, C. Daniel, M. Boujtita and F. Odobel, Dalton Trans., 2013, 10818.

13 B. Bozic-Weber, E. C. Constable, C. E. Housecroft, P. Kopecky, M. Neuburger and J. A. Zampese, Dalton Trans., 2011, 12584.

14 E. Schönhofer, B. Bozic-Weber, C. J. Martin, E. C. Constable, C. E. Housecroft and J. A. Zampese, Dyes Pigm., 2015, 115, 154.

15 B. Bozic-Weber, V. Chaurin, E. C. Constable, C. E. Housecroft, M. Meuwly, M. Neuburger, J. A. Rudd, E. Schönhofer and L. Siegfried, Dalton Trans., 2012, 14157.

16 B. Bozic-Weber, S. Y. Brauchli, E. C. Constable, S. O. Fürer, C. E. Housecroft, F. J. Malzner, I. A. Wright and J. A. Zampese, Dalton Trans., 2013, 12293.

17 B. Bozic-Weber, E. C. Constable, S. O. Fürer, C. E. Housecroft, L. J. Troxler and J. A. Zampese, Chem. Commun., 2013, 49, 7222.

18 S. Y. Brauchli, B. Bozic-Weber, E. C. Constable, N. Hostettler, C. E. Housecroft and J. Zampese, RSC Adv., 2014, 4, 34801.

19 C. L. Linfoot, P. Richardson, T. E. Hewat, P. Moudam, M. M. Forde, A. Collins, F. White and N. Robertson, Dalton Trans., 2010, 8945.

20 F. J. Malzner, S. Y. Brauchli, E. Schönhofer, E. C. Constable and C. E. Housecroft, Polyhedron, 2014, 82, 116.

21 N. Armaroli, G. Accorsi, F. Cardinali and A. Listorti, Top. Curr. Chem., 2007, 280, 69 and references therein.

22 B. Bozic-Weber, S. Y. Brauchli, E. C. Constable, S. O. Fürer, C. E. Housecroft and I. A. Wright, Phys. Chem. Chem. Phys., 2013, 15, 4500.

23 G. J. Kubas, Inorg. Synth., 1990, 28, 68.

24 S. Ito, P. Chen, P. Comte, M. K. Nazeeruddin, P. Liska, P. Péchy and M. Grätzel, Prog. Photovolt.: Res. Appl., 2007, 15, 603.

25 S. Ito, T. N. Murakami, P. Comte, P. Liska, C. Grätzel, M. K. Nazeeruddin and M. Grätzel, Thin Solid Films, 2008, 516, 4613.

26 H. J. Snaith, Energy Environ. Sci., 2012, 5, 6513.

27 H. J. Snaith, Nat. Photonics, 2012, 6, 337. 
28 M. Sandroni, M. Kayanuma, M. Rebarz, H. Akdas-Kilig, Y. Pellegrin, E. Blart, H. Le Bozec, C. Daniel and F. Odobel, Dalton Trans., 2013, 14628.

29 B. Wenger, M. Grätzel and J.-E. Moser, J. Am. Chem. Soc., 2005, 127, 12150.

30 B. Wenger, M. Grätzel and J.-E. Moser, Chimia, 2005, 59, 123.

31 V. K. Thorsmølle, B. Wenger, J. Teuscher, C. Bauer and J.-E. Moser, Chimia, 2007, 61, 631.
32 M. T. Miller, P. K. Gantzel and T. B. Karpishin, Inorg. Chem., 1998, 37, 2285.

33 See for example: G. E. Schneider, A. Pertegás, E. C. Constable, C. E. Housecroft, N. Hostettler, C. D. Morris, J. A. Zampese, H. J. Bolink, J. M. Junquera-Hernández, E. Ortí and M. Sessolo, J. Mater. Chem. C, 2014, 8, 7047.

34 Spartan '14, Wavefunction, Inc., Irvine, CA 92612.

35 S. Y. Brauchli, F. J. Malzner, E. C. Constable and C. E. Housecroft, RSC Adv., 2014, 4, 62728. 